\title{
Multi-Product Lactic Acid Bacteria Fermentations:
}

\section{A Review}

\author{
José Aníbal Mora-Villalobos ${ }^{1}$ (D), Jéssica Montero-Zamora ${ }^{1}$, Natalia Barboza ${ }^{2,3}$, \\ Carolina Rojas-Garbanzo ${ }^{3}$, Jessie Usaga ${ }^{3}$, Mauricio Redondo-Solano ${ }^{4}$, Linda Schroedter ${ }^{5}$, \\ Agata Olszewska-Widdrat ${ }^{5}$ (D) and José Pablo López-Gómez ${ }^{5, *(D)}$ \\ 1 National Center for Biotechnological Innovations of Costa Rica (CENIBiot), National Center of High \\ Technology (CeNAT), San Jose 1174-1200, Costa Rica; amorav@cenat.ac.cr (J.A.M.-V.); \\ jemontero@cenat.ac.cr (J.M.-Z.) \\ 2 Food Technology Department, University of Costa Rica (UCR), San Jose 11501-2060, Costa Rica; \\ natalia.barboza@ucr.ac.cr \\ 3 National Center for Food Science and Technology (CITA), University of Costa Rica (UCR), \\ San Jose 11501-2060, Costa Rica; carolina.rojasgarbanzo@ucr.ac.cr (C.R.-G.); jessie.usaga@ucr.ac.cr (J.U.) \\ 4 Research Center in Tropical Diseases (CIET) and Food Microbiology Section, Microbiology Faculty, \\ University of Costa Rica (UCR), San Jose 11501-2060, Costa Rica; mauricio.redondosolano@ucr.ac.cr \\ 5 Bioengineering Department, Leibniz Institute for Agricultural Engineering and Bioeconomy (ATB), \\ 14469 Potsdam, Germany; lschroedter@atb-potsdam.de (L.S.); \\ aolszewska-widdrat@atb-potsdam.de (A.O.-W.) \\ * Correspondence: plopezgomez@atb-potsdam.de; Tel.: +49-(0331)-5699-857
}

Received: 15 December 2019; Accepted: 4 February 2020; Published: 10 February 2020

\begin{abstract}
Industrial biotechnology is a continuously expanding field focused on the application of microorganisms to produce chemicals using renewable sources as substrates. Currently, an increasing interest in new versatile processes, able to utilize a variety of substrates to obtain diverse products, can be observed. A robust microbial strain is critical in the creation of such processes. Lactic acid bacteria (LAB) are used to produce a wide variety of chemicals with high commercial interest. Lactic acid (LA) is the most predominant industrial product obtained from LAB fermentations, and its production is forecasted to rise as the result of the increasing demand of polylactic acid. Hence, the creation of new ways to revalorize LA production processes is of high interest and could further enhance its economic value. Therefore, this review explores some co-products of LA fermentations, derived from $\mathrm{LAB}$, with special focus on bacteriocins, lipoteichoic acid, and probiotics. Finally, a multi-product process involving LA and the other compounds of interest is proposed.
\end{abstract}

Keywords: LAB metabolites; probiotics; lactic acid; lipoteichoic acid; bacteriocins; biomass

\section{Introduction}

During the last decades, the interest in the development and utilization of more sustainable energy and chemical resources increased due to worldwide concerns regarding fossil-fuel depletion and environmental protection [1]. Since the middle of the 19th century, the petrochemical industry is responsible for meeting the world's chemical and energy needs. Nevertheless, the finite nature of oil, its price volatility, and the environmental impact of its utilization are some of the reasons that encouraged research into alternative ways of meeting the energy and chemical demands of a continuously growing population. Industrial biotechnology is an expanding field, with special focus on the application of microorganisms to produce energy and chemicals using renewable resources as substrates.

Currently, there are several well-established single product bioprocesses which show economic and environmental feasibility. However, multi-product routes, through the valorization of residues and 
by-products, were proposed to improve industrial single-product biotechnological processes [2]. One example is the use of cellulose and hemicellulose from sugarcane bagasse (a residue obtained during the bioethanol production and usually used for energy generation) for the production of value-added chemicals [3]. Likewise, glycerol, a by-product of the biodiesel industry with low value in the market, is targeted as a molecule of interest in fermentation processes. Such multi-product processes, based on the conversion of renewable materials into biobased products, are known as biorefineries [4].

The study, development, and application of robust microbial strains, able to utilize a variety of substrates and to produce a wide range of products, is considered a milestone in the development of biorefineries [4]. Lactic acid bacteria (LAB) are a diverse group with recognized potential for the development of integrated biorefineries [5]. LAB are non-sporulating, non-motile, acid-tolerant, non-respiring but aerotolerant, catalase-negative, Gram-positive cocci or rods. They are characterized by the production of lactic acid (LA) as the major end metabolic product of carbohydrate fermentation [6-9]. Given the lack of a functional respiratory system, LAB obtain energy through substrate-level phosphorylation following two metabolic pathways for hexose fermentation, i.e., homofermentative and heterofermentative. As shown in Figure 1, the first pathway is based on glycolysis with the production of mainly LA, whereas the second one, known as the pentose phosphate pathway, is characterized for the production of $\mathrm{CO}_{2}$ and ethanol, or acetate in addition to LA [6].

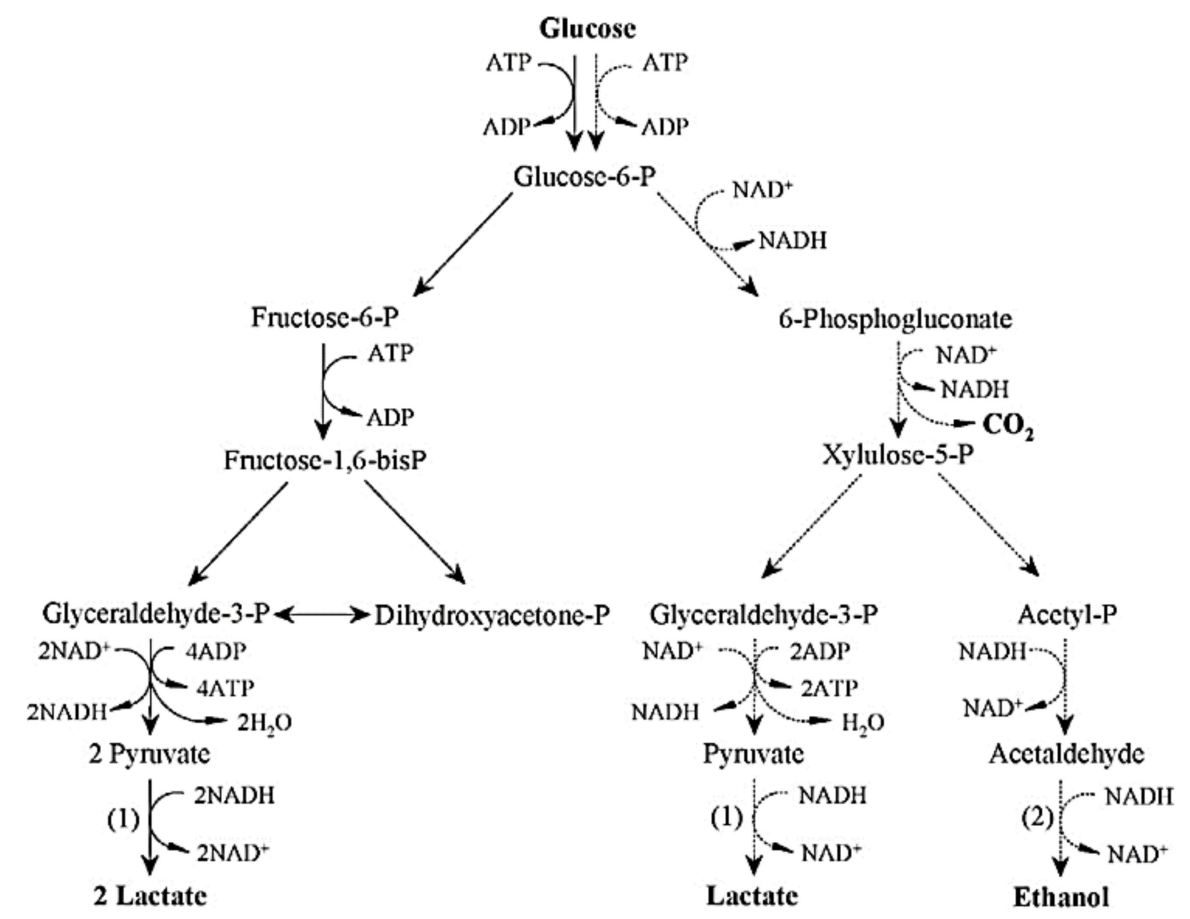

Figure 1. Metabolic pathways of homofermentative (solid line) and heterofermentative (dotted line) lactic acid bacteria: $\mathrm{P}$, phosphate; ADP, adenosine 5'-diphosphate; ATP, adenosine $5^{\prime}$-triphosphate; $\mathrm{NAD}^{+}$, nicotinamide adenine dinucleotide; $\mathrm{NADH}$, nicotinamide adenine dinucleotide (reduced form); (1), lactate dehydrogenase; (2), alcohol dehydrogenase (from Reference [8], licensed under CC BY-NC 4.0 at https://www.ftb.com.hr/80-volume-44-issue-no-2/445-biotechnological-production-of-lactic-acidand-its-recent-applications).

Most LAB are part of the phylum Firmicutes, class Bacilli, and order Lactobacillales. The order Lactobacillales includes six families, i.e., Aerococcaceae, Carnobacteriaceae, Enterococcaceae, Lactobacillaceae, Leuconostocaceae, and Streptococcaceae, over 30 genera, and more than 300 species, a number that continues rising as novel species are discovered [10,11]. The genus Bifidobacterium (family Bifidobacteriaceae) is also included in the LAB group, although it belongs to the phylum Actinobacteria [6]. LAB identification is based on the criteria originally stated by Orla-Jensen in 1919 [12], which includes morphology, mode of glucose fermentation, growth temperature ranges, and 
sugar utilization patterns [6], in addition to phylogenetic analysis based on 16S ribosomal RNA (rRNA) gene sequences [8]. Moreover, because some LAB species share high sequence similarities within the groups, some housekeeping genes are used as alternative markers. Currently, whole-genome sequencing is a common tool for LAB identification in the laboratory $[6,8]$. Species identification, using sequencing, provides essential information to conduct genome editing of food-grade LAB, i.e., using clustered regularly interspaced short palindromic repeats (CRISPR) tools [13,14]. Potential applications of these technologies include the development of therapeutic probiotics and strains with resistance against viruses $[14,15]$.

Lactic acid bacteria are ubiquitous and widespread in nature, found in a variety of nutrient-rich habitats such as animals, food, feed, humans, plants, and soil $[10,16]$. Isolation of LAB from composts, fermented foods, gastrointestinal and vaginal tracts, plant surfaces, and silages, to name a few, was reported [8]. Owing to their versatile metabolism and their ability to synthesize a wide range of beneficial metabolites in addition to LA, LAB are extensively used in biotechnology, food, and therapeutic products. Some of the applications of LAB include their use as additional hurdles for spoilage and pathogenic microorganisms, antifungal and anti-mycotoxigenic agents, bacteriocin producers, nutraceutical producers, probiotics and starter cultures, among others [6,10,16-19]. After safety assessment, the United States (US) Food and Drug Administration (FDA) and the European Food Safety Agency (EFSA) included numerous LAB species and food additives derived from them on the generally recognized as safe (GRAS) inventory or accordingly granted the qualified presumption of safety (QPS) status [6,20].

This review aims to highlight the different industrial uses of $\mathrm{LAB}$, from probiotics to their use as biofactories of metabolites of interest. Furthermore, it investigates the potential of homofermentative LAB for simultaneously producing several products of interest. Finally, a multi-product biorefinery process is proposed.

\section{Potential Uses of Lactic Acid Bacteria}

Lactic acid bacteria are mainly used in fermentation systems which may be performed in solid (SSF) or liquid states (SLF). SLF is the most studied and industrially implemented approach, which targets the isolation of organic acids (mainly lactic acid), ethanol, bioactive peptides, among others. After fermentation, isolation and purification steps are needed to extract these compounds from the supernatant or the biomass phase. Nevertheless, in addition to the supernatant products, some LAB biomass, traditionally used in single-product fermentation processes, may also have probiotic potential. Thus, their isolation and further use, considering a multi-product process approach, could add value to the product. Figure 2 summarizes some of the most relevant compounds linked to LAB that are further discussed in this review.

Among LAB metabolites, LA and bacteriocins are examples of extracellular bacterial products that are continuously produced during growth and remain in the fermented broth. By the end of the fermentation, biomass is normally discarded; however, recently, the interest in biomass as an added-value product gained attention. Biomass is used as a protein source for the supplementation of by-products utilized in green processes; however, if the bacterial genus used is recognized as a probiotic, applications in the food industry may also be developed. Furthermore, the cell wall of LAB consists of a thick multilayered sacculus made of peptidoglycan, teichoic and LTAs, cell-wall polysaccharides, and cell surface proteins, which are also compounds with great potential for biotechnological applications [21]. With an appropriate methodology, each of these components can be separated and purified, and many applications in the food and pharmaceutical industries may be found, e.g., LTA may be used for the treatment or prevention of oral infectious diseases or as an anti-inflammatory agent [22-24]. Therefore, the multiple metabolic pathways of LAB may be an advantage for the development of more efficient and sustainable multi-product processes. 


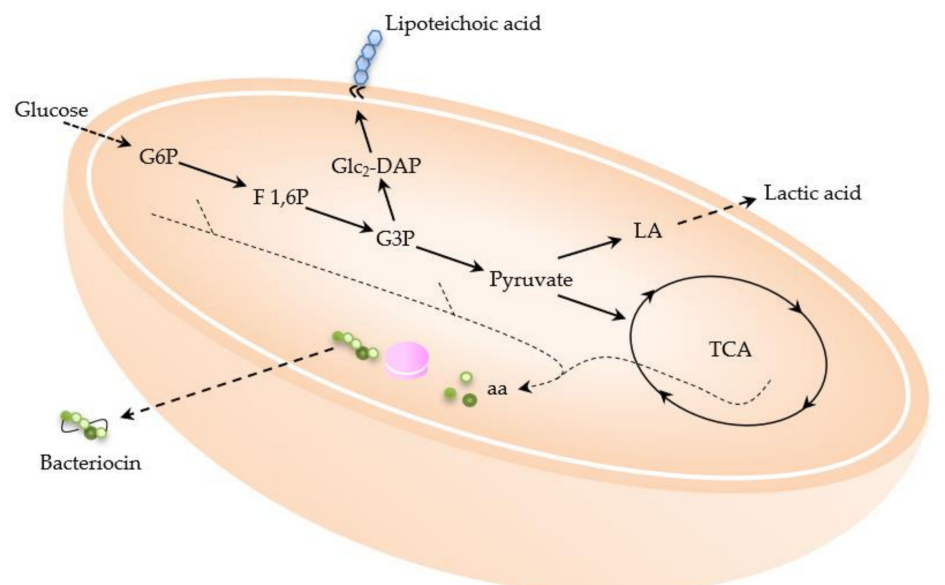

Figure 2. Illustration of the co-production of compounds in lactic acid bacteria (LAB). Extracellular products such as lactic acid (LA) and bacteriocins are synthetized and excreted from the cell, whereas lipoteichoic acid (LTA) accumulates in the cell walls of the microorganism.

\subsection{Products Present in Supernatant}

While growing, microorganisms produce and secrete different metabolites to their surrounding environment. These molecules, which are excreted to the supernatant during fermentation, provide information regarding changes in microbial metabolism and can be purified for certain purposes. Extracellular metabolites are mainly produced as by-products of microbial metabolic activities, and their production is influenced by environmental conditions such as temperature, $\mathrm{pH}$, nutrients, and others [25]. LAB require relatively simple substrates in order to excrete, for instance, lactic acid or bacteriocins, as described in Sections 2.1.1 and 2.1.2. Unlike intracellular metabolites, which require cell disruption in order to be quantified and used, the separation of products present in the supernatant can be easily achieved via simple techniques such as centrifugation and filtration.

\subsubsection{Lactic Acid}

LA (2-hydroxypropanoic acid) is a chiral molecule with two optical enantiomers, L-(+) and D-(-), which can be produced via either chemical synthesis or microbial fermentation. Nevertheless, the vast majority of LA in the world is produced via biotechnological routes (via homo- and heterofermentative LAB). Furthermore, some LAB species can synthesize only one of the two enantiomers, i.e., L-(+) and $\mathrm{D}-(-)$, which allows the utilization of the product for some specialized applications. Most of the biotechnological LA production targets the $\mathrm{L}-(+)$ enantiomer, partly because the $\mathrm{D}-(-)$ cannot be metabolized by animal cells, which restricts its utilization in some cases, e.g., the food industry. Additionally, the production of polylactic acid, which increased the interest in LA and is now a market driver in its production [26], requires high enantiomeric purities [27].

Due to its technical simplicity, LA is traditionally produced in batch processes; nonetheless, other cultivation strategies such as fed-batch were also investigated [28]. Application of fed-batch conditions offers several advantages such as improving the productivity and reducing substrate inhibition issues [28]. Recently, it was stated that continuous fermentation of LA is most economically viable, and favoring this process in the future is highly recommended [29].

High titers of L-LA were achieved in fed-batch processes: $215.3 \mathrm{~g} \cdot \mathrm{L}^{-1}$ of $100 \%$ optically pure L-LA was produced from glucose using a genetically modified Lactobacillus paracasei strain reaching a productivity of $1.79 \mathrm{~g} \cdot \mathrm{L}^{-1} \cdot \mathrm{h}^{-1}$ [28]. A fed-batch fermentation, combined with the increase in temperature during the process, enabled L. rhamnosus to produce $210 \mathrm{~g} \cdot \mathrm{L}^{-1} \mathrm{~L}-\mathrm{LA}$ from defatted rice bran with a productivity of $2.56 \mathrm{~g} \cdot \mathrm{L}^{-1} \cdot \mathrm{h}^{-1}$. Nevertheless, the optical purity of the product was not stated in the study [30]. Enterococcus mundtii was tested in several artificial sugars and sugar mixtures of glucose, xylose, and cellobiose [31-33]. The best titer in these studies was reported from a fed-batch 
fermentation with a cellobiose-xylose mixture, reaching $163 \mathrm{~g} \cdot \mathrm{L}^{-1} \mathrm{~L}-(+)-\mathrm{LA}$ of $>99 \%$ optical purity in $240 \mathrm{~h}$ [33]. L-(+)-LA titers of 182, 134.9, and $93 \mathrm{~g} \cdot \mathrm{L}^{-1}$ were achieved with E. faecalis in batch fermentations utilizing glucose, sugar molasses, and oak wood chips, respectively [34-36]. Overall productivities using glucose, sugar molasses, and oak wood chips were $5.0,4.3$, and $1.7 \mathrm{~g} \cdot \mathrm{L}^{-1} \cdot \mathrm{h}^{-1}$, respectively. The optical purities for the LA obtained through the sugar molasses and oak wood fermentations were $>98 \%$ and $96 \%$, respectively.

Batch fermentation studies using E. faecalis also focused on scale-up, starting from working volumes of $3 \mathrm{~L}$, going up to $5.2 \mathrm{~m}^{3}$ by utilizing waste plywood chips as a substrate. At a 3-L scale process, $102.4 \mathrm{~g} \cdot \mathrm{L}^{-1}$ of $>99 \%$ pure $\mathrm{L}-(+)$-LA was produced, with a productivity of $1.28 \mathrm{~g} \cdot \mathrm{L}^{-1} \cdot \mathrm{h}^{-1}$. On the other hand, at $5.2-\mathrm{m}^{3}$ scale, only $91.5 \mathrm{~g} \cdot \mathrm{L}^{-1}$ of LA was obtained, with a productivity of 0.88 $\mathrm{g} \cdot \mathrm{L}^{-1} \cdot \mathrm{h}^{-1}$. Additionally, a longer lag phase was observed due to the differences in the oxygen levels of both bioreactors tested [37]. Wee et al. [38] conducted a 200-L pilot-scale batch using corn steep liquor as a nitrogen source and glucose as a the carbon substrate. In this study, Lactobacillus species RKY2 grown in a glucose concentrations of up to $125 \mathrm{~g} \cdot \mathrm{L}^{-1}$ led to a maximum $\mathrm{L}-(+)-\mathrm{LA}$-titer of $115.1 \mathrm{~g} \cdot \mathrm{L}^{-1}$ and a productivity of $1.1 \mathrm{~g} \cdot \mathrm{L}^{-1} \cdot \mathrm{h}^{-1}$, albeit with an optical purity of $70 \% \mathrm{~L}-(+)-\mathrm{LA}$ [38].

Regarding the production of D-(-)-LA, $102.3 \mathrm{~g} \cdot \mathrm{L}^{-1}$ and $77.8 \mathrm{~g} \cdot \mathrm{L}^{-1}$ of $>99 \%$ optical purity was obtained while conducting simultaneous saccharification and fermentation processes with lignocellulosic substrates. In these studies, L. plantarum reached a productivity of $0.7 \mathrm{~g} \cdot \mathrm{L}^{-1} \cdot \mathrm{h}^{-1}$ in delignified kraft pulp, whereas Pediococcus acidilactici was able to produce $1.0 \mathrm{~g} \cdot \mathrm{L}^{-1} \cdot \mathrm{h}^{-1}$ in corn stover hydrolysate $[39,40]$.

Numerous investigations focused on transferring suitable lactate dehydrogenase (LDH) genes from LAB to yeast species. The acid tolerance of yeast enables it to grow at lower $\mathrm{pH}$ values of $4-5$. This condition not only reduces the input of neutralization agents, but also allows the utilization of a wider range of substrates [41]. For example, the combination of D-LDH genes from Leuconostoc mesenteroides with Saccharomyces cerevisiae resulted in titers as high as $112 \mathrm{~g} \cdot \mathrm{L}^{-1}$ of $\mathrm{D}-(-)-\mathrm{LA}$ in a fed-batch process at a productivity of $2.2 \mathrm{~g} \cdot \mathrm{L}^{-1} \cdot \mathrm{h}^{-1}$ [42-44].

Continuous fermentation, with the implementation of cell recycle, offers an interesting approach for industrial-scale LA production; this option increases the overall operation time and the productivity by enabling high cell densities [45]. By employing E. faecalis in cell recycle continuous fermentation, an L-(+)-LA titer of $90 \mathrm{~g} \cdot \mathrm{L}^{-1}$ and a productivity of $3.72 \mathrm{~g} \cdot \mathrm{L}^{-1} \cdot \mathrm{h}^{-1}$ were achieved using glucose as a carbon source. The dilution rate was set at $0.04 \mathrm{~h}^{-1}$ and residual sugars in the bioreactor were $<5$ $\mathrm{g} \cdot \mathrm{L}^{-1}$; however, the optical purity of the product was not specified [46]. Cell recycle fermentation with E. mundtii led to a titer of $41 \mathrm{~g} \cdot \mathrm{L}^{-1}$ optically pure L-(+)-LA (> 99.9\%) from xylose, reaching a productivity of $6.15 \mathrm{~g} \cdot \mathrm{L}^{-1} \cdot \mathrm{h}^{-1}$ at a dilution rate of $0.155 \mathrm{~h}^{-1}$. Residual xylose $\left(11.1 \mathrm{~g} \cdot \mathrm{L}^{-1}\right)$ remained in the process, as well as several by-products including acetic and formic acids and ethanol, which amounted to $3 \mathrm{~g} \cdot \mathrm{L}^{-1}$ [47]. A high productivity of $57 \mathrm{~g} \cdot \mathrm{L}^{-1} \cdot \mathrm{h}^{-1}$ and a titer of $92 \mathrm{~g} \cdot \mathrm{L}^{-1}$ of L-(+)-LA from glucose were obtained after fermentation with $L$. rhamnosus by connecting two bioreactors, with membrane cell recycle, in series. This system was run at an overall dilution rate of $0.62 \mathrm{~g} \cdot \mathrm{L}^{-1} \cdot \mathrm{h}^{-1}$ and residual sugars were reduced to $<3 \mathrm{~g} \cdot \mathrm{L}^{-1}$, but the optical purity of the acid was not analyzed [48]. Furthermore, lignocellulosic substrates like corn cob hydrolysates and oak wood chips were utilized for continuous fermentation employing L. casei and Lactobacillus sp. RKY2. Titers of $108.9 \mathrm{~g} \cdot \mathrm{L}^{-1}$ and 42 $\mathrm{g} \cdot \mathrm{L}^{-1}$ at productivities of $13.1 \mathrm{~g} \cdot \mathrm{L}^{-1} \cdot \mathrm{h}^{-1}$ and $6.7 \mathrm{~g} \cdot \mathrm{L}^{-1} \cdot \mathrm{h}^{-1}$, respectively, were achieved in these studies; only the latter reported the L-(+)-LA optical purity $(70 \%)[49,50]$.

Concerning LAB, several studies focused on the co-production of other metabolites alongside LA. For instance, Streptococcus species coproduced hyaluronic acid or biogas; however, in both cases, downstream aspects of the process were not considered [51,52]. More typically, processes aim to produce LA while concurrently trying to achieve high biomass concentration, which can be used as a high-quality feed or probiotic food supplement [53-57]. 


\subsubsection{Bacteriocins}

Bacteriocins are small, ribosomally synthesized peptides with antimicrobial properties. Normally produced by $\mathrm{LAB}$, these compounds are active against other Gram-positive bacteria or closely related microorganisms. Given their antimicrobial properties, some bacteriocins such as nisin and pediocin are used as preservatives in food products in order to inhibit the growth of spoilage and pathogenic microorganisms. Additionally, bacteriocins are believed to contribute to the competitiveness of the producer cells, which is an important feature for some LAB used as starter cultures in fermented foods [58]. The general antimicrobial mechanism of bacteriocins is based on the disruption of the cell membrane via either pore formation or a "detergent effect", as in the case of nisin [59].

Bacteriocins are typically low-weight, cationic, and hydrophobic molecules composed of 20 to 60 amino-acid residues. They are normally synthesized along with a leader sequence that is cleaved during maturation and then released from the cell [59]. Based on their general structure and properties, bacteriocins can be classified into three different categories:

- Class I (lantibiotics): peptides containing lanthionine (a non-canonical amino acid). These can be elongated with a net positive charge (sub-class A, e.g., nisin), or globular with negative or no charge (sub-class B, e.g., mersacidin).

- Class II: heat-stable peptides, not containing lanthionine. Their sub-classes depend manly on the activity (sub-class A, e.g., pediocin; sub-class B, e.g., lactococcin, plantaricin; sub-class C, e.g., acidocin).

- Class III: large, heat-labile peptides, not very well characterized. They are lytic proteins often classified as murein-hydrolases (e.g., helveticin).

Despite the variety of antimicrobial peptides produced by LAB, only nisin and pediocin are commercially available, mainly used as food additives, especially in dairy products [58]. Nevertheless, due to the increase in antibiotic-resistant strains and the growing demand for minimally processed foods and clean labels, the research and development of novel antimicrobial peptides is one of the main interests within the LAB biotechnological sector. Even though new bacteriocins or bacteriocin-like peptides from LAB are discovered every year, challenges for further commercial application of these compounds still hinder their utilization. Before considering the industrial production of bacteriocins, studies to develop optimized processes for bacteriocin synthesis and the subsequent purification of the compounds are still necessary.

Regarding bacteriocin production, most studies combined bacterial growth and antimicrobial production. So far, the most relevant factors reported are related to the fermentation conditions, e.g., media composition, acidity levels, and incubation temperature. Some studies additionally reported microbial modeling and optimization processes to define the best conditions for bacteriocin synthesis (Table 1). 
Table 1. Culture conditions necessary to attain high bacteriocin titers from Lactobacillus according to scientific literature ${ }^{\text {a }}$.

\begin{tabular}{|c|c|c|c|c|c|c|c|}
\hline Microorganism & $\begin{array}{l}\text { Optimized Bacteriocin } \\
\text { Level }\left(\mathrm{AU} \cdot \mathrm{mL}^{-1} \times 10^{3}\right)\end{array}$ & Media & Relevant Media Component ${ }^{b}$ & $\mathrm{pH}^{\mathrm{c}}$ & $\mathrm{T}\left({ }^{\circ} \mathrm{C}\right)$ & Other Considerations ${ }^{d}$ & Reference \\
\hline L. lactis subsp. lactis & 131 & M17 broth & Lactose $(3.0 \%)$ & 6.0 & 30 & Early stationary phase & [60] \\
\hline L. amylovorus & 25.6 & $\begin{array}{l}\text { Sourdough simulation } \\
\text { medium }\end{array}$ & $\mathrm{NaCl}\left(10 \mathrm{~g} \cdot \mathrm{L}^{-1}\right)$ & 5.4 & 37 & NR & [61] \\
\hline L. amylovorus & 25.6 & Modified MRS & $\begin{array}{l}\text { Glucose }\left(11 \mathrm{~g} \cdot \mathrm{L}^{-1}\right), \text { nitrogen } \\
\text { mixture }\left(25 \mathrm{~g} \cdot \mathrm{L}^{-1}\right)\end{array}$ & 5.0 & 37 & $\begin{array}{l}\text { Continuous fed-batch } \\
\text { fermentation }\end{array}$ & [62] \\
\hline L. lactis sbsp. lactis & 15.4 & Optimized medium & Various ingredients & 5.5 & 30 & Max activity after $7 \mathrm{~h}$ & [63] \\
\hline L. acidophilus & 12.8 & MRS broth & Glucose $\left(20 \mathrm{~g} \cdot \mathrm{L}^{-1}\right)$ & 6.5 & 37 & $100 \mathrm{rpm}$ & [64] \\
\hline L. plantarum & 12.8 & MRS broth & $\begin{array}{c}\text { Tryptone }\left(10 \mathrm{~g} \cdot \mathrm{L}^{-1}\right) \text {, meat } \\
\text { extract }\left(5 \mathrm{~g} \cdot \mathrm{L}^{-1}\right) \text {, yeast extract }(5 \\
\left.\mathrm{g} \cdot \mathrm{L}^{-1}\right), \text { maltose }\left(20 \mathrm{~g} \cdot \mathrm{L}^{-1}\right) \\
\text { mannose }\left(20 \mathrm{~g} \cdot \mathrm{L}^{-1}\right)\end{array}$ & $5.5-6.5$ & 30 & Max activity after $14 \mathrm{~h}$ & {$[64,65]$} \\
\hline L. pentosus & 6.4 & MRS & $\begin{array}{l}\text { Tryptone }\left(12.5 \mathrm{~g} \cdot \mathrm{L}^{-1}\right) \text {, meat } \\
\text { extract }\left(7.5 \mathrm{~g} \cdot \mathrm{L}^{-1}\right) \\
\text { maltose }\left(20 \mathrm{~g} \cdot \mathrm{L}^{-1}\right), \text { glucose } \\
\left(10-20 \mathrm{~g} \cdot \mathrm{L}^{-1}\right), \text { no glycerol }\end{array}$ & n.r. & 30 & NR & [66] \\
\hline L. sakei sbsp. sakei & 10.9 & MRS broth & $\begin{array}{l}\text { Glucose }\left(5.5 \mathrm{~g} \cdot \mathrm{L}^{-1}\right) \text { and } \\
\text { Tween- } 80\left(10.5 \mu \mathrm{L} \cdot \mathrm{mL}^{-1}\right)\end{array}$ & 6.0 & 30 & $\begin{array}{c}\text { Media supplemented with } \\
\text { Tween-20, sodium citrate, } \\
\mathrm{KCl} \text {, and cysteine }\end{array}$ & [67] \\
\hline Ln. mesenteroides & 10.2 & MRS & $\begin{array}{c}\text { Glucose }(4.5 \%) \text {, peptone }(8 \%) \\
\text { yeast extract }(1.5 \%)\end{array}$ & 5.5 & 25 & $\mathrm{NR}$ & [67] \\
\hline L. plantarum & 9.0 & MRS & $\mathrm{KH}_{2} \mathrm{PO}_{4}\left(2,5\right.$, and $\left.10 \mathrm{~g} \cdot \mathrm{L}^{-1}\right)$ & n.r. & 30 & & {$[64,65]$} \\
\hline L. brevis & 6.4 & MRS & $\begin{array}{c}\text { Yeast extract }(2-3 \%), \mathrm{NaCl} \\
(1-2 \%), \text { glucose }(1 \%) \\
\text { Tween-80 }(0.5 \%)\end{array}$ & n.c. & 30 & $\begin{array}{l}\text { Final } \mathrm{pH} \text { between } 3.86 \\
\text { and } 4.04\end{array}$ & [68] \\
\hline L. amylovorus & 6.4 & MRS & Glucose $\left(20 \mathrm{~g} \cdot \mathrm{L}^{-1}\right)$ & n.r. & 37 & $\mathrm{NR}$ & [69] \\
\hline L. plantarum & 6.4 & MRS & $\begin{array}{c}\text { Meat extract }(1.5 \%) \text {, yeast } \\
\text { extract }(1 \%), \text { biotin }(0.01 \\
\left.\mathrm{mg} \cdot \mathrm{L}^{-1}\right)\end{array}$ & 6.5 & 30 & NR & [70] \\
\hline L. plantarum & 6.4 & MRS & $\begin{array}{l}\text { Meat and yeast extract ( } 20 \\
\left.\mathrm{~g} \cdot \mathrm{L}^{-1}\right) \text {, maltose }(3.0 \%) \text {, no } \\
\text { glycerol }\end{array}$ & 6.5 & 30 & NR & {$[64,65]$} \\
\hline L. acidophilus & 6.4 & MRS & Glucose $\left(20 \mathrm{~g} \cdot \mathrm{L}^{-1}\right)$ & 6.0 & 37 & $100 \mathrm{rpm}$ & [71] \\
\hline L. amylovorus & 5.5 & $\begin{array}{l}\text { Sourdough simulation } \\
\text { medium }\end{array}$ & $\begin{array}{l}\text { Yeast extract }\left(12 \mathrm{~g} \cdot \mathrm{L}^{-1}\right) \\
\text { tryptone }\left(10 \mathrm{~g} \cdot \mathrm{L}^{-1}\right)\end{array}$ & 5.4 & 37 & NR & [72] \\
\hline L. lactis & 2.1 & Cultural medium & $\begin{array}{l}\text { Soybean peptone }\left(4.49 \mathrm{~g} \cdot \mathrm{L}^{-1}\right) \\
\mathrm{KH}_{2} \mathrm{PO}_{4}\left(28.42 \mathrm{~g} \cdot \mathrm{L}^{-1}\right)\end{array}$ & 6.8 & 30 & Shaking at $180 \mathrm{rpm}$ & [73] \\
\hline
\end{tabular}

a Bacteriocin activity values reported after testing the conditions individually or in combination (according to the reference). ${ }^{\mathrm{b}}$ Ingredients added to the basic formulation of each culture media. ${ }^{\mathrm{c}} \mathrm{pH}$ levels at the beginning of the process. In some cases, acidity levels increased by the end of fermentation. ${ }^{\mathrm{d}}$ NR: no other relevant factors were reported. 
Moreover, bacteriocins are a group of molecules that are normally secreted into the medium. Due to the complexity of the chemical structures, their purification is often based on the affinity to organic solvents. For the isolation of each specific bacteriocin, parameters such as solubility and stability at a given salt concentration and $\mathrm{pH}$ should be taken into consideration. An organic extraction can be efficiently incorporated into the LA downstream process due to the poor solubility of LA in organic solvents.

\subsection{Use of LAB-Biomass}

After the production of extracellular metabolites, the whole cell can be used as a product (probiotics), with an easy application since no extraction is required. Contrary to biomass, intracellular metabolites require extraction and purification methods to disrupt the mechanical barrier and to obtain the compound of interest. This is usually achieved using extracting solvents and separation techniques, which result in the extraction of both small and large molecules into the extraction solution [74].

\subsubsection{Probiotics}

Some LAB were characterized for their probiotic potential. This term refers to "live microorganisms that, when administered in adequate amounts, confer a health benefit on the host" [75]. An increased interest in the use of these microorganisms, to treat specific diseases or their associated symptoms, prompted the execution of numerous comprehensive studies. Probiotics are generally added to foods as supplements and provide benefits to consumers, such as the maintenance of a healthy intestinal microbiota, lower cholesterol levels, and regulation of the immune response [76,77]. They are mainly used to treat digestive disorders and gastrointestinal diseases, as well as skin, mouth, urinary tract, and respiratory diseases [77-82].

Most of the probiotic species commercially available belong to the Lactobacillus, Enterococcus, Streptococcus, and Bifidobacterium genera [78,83-86]. Other genera such as Roseburia spp., Akkermansia spp., Propionibacterium spp., and Faecalibacterium spp. show promising characteristics and are currently under evaluation [87]. It is worth noting that most of the information related to probiotic characterization is derived from in vitro cell culture studies or in vivo testing using models, and this information must be corroborated in order to use the results at an industrial scale $[87,88]$. In recent years, there was growing interest in the characterization of new LAB isolates from different sources to use them as probiotics or for other applications [89]. Yet, in parallel to isolation and characterization efforts, identification at a species level (and, in some cases, at a strain level) is necessary for commercial purposes.

The most common identification method is based on the sequence of the conserved region of the 16S rRNA gene; normally, this is used to define the phylogeny of the isolates [90,91]. When several strains are studied, other molecular tools can be used for differentiation and selection of the isolates, e.g., rep-PCR DNA fingerprinting, pulsed field gel electrophoresis (PFGE), denaturing gel gradient electrophoresis (DGGE), randomly amplified polymorphic DNA (RAPD), and, more recently, whole-genome sequencing.

Probiotic evaluation is based on the ability of the strain to survive the gastrointestinal tract conditions, such as low $\mathrm{pH}$ and lysozyme resistance [92,93]. Other characteristics such as bile resistance, antibiotic susceptibility, and the ability to adhere to the intestinal mucosa, human epithelial cells, or different cell lines are also used to analyze new probiotic isolates [93-95].

Under normal conditions, probiotics produce metabolites with antimicrobial activity such as exopolysaccharides, biosurfactants, bacteriocins, and organic acids. Moreover, theses microorganisms use an agglomeration mechanism that facilitates the excretion of pathogens from the digestive system. Antagonism is also associated with the production of lactic and acetic acids during carbohydrate metabolism, which favors a lower $\mathrm{pH}$ of the medium and inhibits the growth of some pathogenic microorganisms [96-98]. Therefore, antagonism toward pathogenic bacteria is also a desirable characteristic in order to be considered as a probiotic. 
Regarding the immunological response, probiotics may improve it, stimulating host cell antibody secretion. Increased immune response can be evaluated through the co-culture of probiotics with immune system cells, which allows the detection and quantification of cytokines; these compounds are indicative of an inflammatory process $[99,100]$. Through in vivo studies, promising results concerning diseases associated with the immune system were reported, e.g., inflammatory bowel diseases [101] and symptoms caused by allergies [102].

There is an increased interest in understanding how probiotics interact with the host. Currently, many studies are focused on the modulation of the immune response, production of organic acids and antimicrobial compounds, interaction with host resident microbiota, improvement of the integrity of the intestinal barrier, and production of secondary metabolites beneficial to the host [87]. However, it is important to evaluate potential probiotic microorganisms to confirm their benefits to human health and to demonstrate their correct use.

\subsubsection{Lipoteichoic Acid (LTA)}

Microbial plasma membranes are surrounded by a wall which allows the classification of bacteria as Gram-positive and Gram-negative. The cell wall of Gram-positive bacteria and the outer membrane of Gram-negative bacteria contain anionic lipid molecules such as LTA and lipopolysaccharide (LPS), respectively [103,104]. LTA molecules are composed of a glycolipid and hydrophilic polymer of glycerophosphate covalently linked [104-106]. LTA was firstly isolated from L. arabinosus in the 1960s. Since then, different studies reported LTA structural and functional variations according to the genera and species of bacteria $[107,108]$. At the cellular level, LTA function is associated with the regulation of cell-wall autolytic enzymes during cell division, which is important for cell growth and proliferation [109]. At an industrial level, LTA shows a variety of potential applications including the enrichment of food matrices and the development of new pharmaceutical products.

Several studies showed that LTA possesses anti-biofilm properties with the potential to treat or prevent oral infectious diseases. Moreover, LTA also showed anti-inflammatory activity for the treatment of colitis and immunomodulation properties [22-24]. Weill et al. [110] performed in vivo assays in mice and proved that oral administration of pure LTA from probiotic L. rhamnosus GG (ATCC 53103) can modulate the immune-suppressive effect of ultraviolet radiation and skin tumor development. Nevertheless, Brauweiler et al. reported that LTA from Staphylococcus aureus promotes keratinocyte proliferation and inhibits the expression of skin barrier proteins [111]. The wide variety of biological effects shown by LTA from different bacteria highlights the need for a better understanding of the mechanisms implicated on its biological response and the chemical composition of the LTA extracted from different sources.

The first reports regarding the recovery of LTA were published in 1975. The extractions were performed using organic solvents at high temperatures [112]. Years later, Morath et al. [113] reported a modification based on the substitution of chromatography technique for extraction with organic solvents in order to increase that yield of purification. However, those two downstream techniques are not environmentally friendly; therefore, alternative technologies, such as membrane separation, should be evaluated for purifying LTA. This is one of the main opportunities within the research and development of novel recovery processes for this compound.

\subsection{Other Compounds with Industrial Potential Produced by $L A B$}

As mentioned before, $\mathrm{LAB}$ is one of the most extended groups of prokaryotes used within the industry mainly due to the biotechnological production of LA and its use as a probiotic. LAB is a group with great potential for the production of fine chemicals due to its capacity to synthesize a large number of bioactive molecules, from which many biological activities were reported [112]. Furthermore, current advances in synthetic biology tools facilitated the development of novel strains able to produce a vast range of molecules such as flavors, antimicrobials, pharmaceuticals, texturizing compounds, vitamins, sweeteners, and nutraceuticals, among others (Table 2) [114]. From an industrial 
point of view, Streptococcaceae and Lactobacillaceae represent the most important taxa since they include the highest number of commercialized LAB [115].

Except for the industrial production of probiotics, cell biomass is normally treated as a by-product in most biotechnological processes. Even in the case where cells are used as catalysts, these are eventually discarded. However, LAB cells contain different compounds with commercial value, such as LTA or conjugated linoleic acid (CLA). CLA possesses great potential as a pharmaceutical product, and it can be produced by LAB via linoleic acid isomerization or from castor oil via ricinoleic acid dehydration. Currently, CLA is produced through the chemical isomerization of linoleic acid, which results in the production of undesired isomers. LAB produces the CLA isomers (cis-9, trans-11; trans-9, trans-11; trans-9, cis-11) at different ratios, but strains that produce specific isomers were already identified [116,117]. Up to 70\% of CLA is accumulated intracellularly or associated with cells; this means that LTA and CLA would be separated in the early stages of the downstream process where cells are discarded, while the supernatant follows the pipeline of purification.

In the case of LA recovery and purification after cell separation, the supernatant is normally filtrated to eliminate cell debris and macromolecules. After this step, organic acids such as azelaic acid (AA) and caproic acid (CA) can be separated from the flow through an organic extraction. AA is a C7 saturated dicarboxylic acid with antibacterial properties; meanwhile, CA is a C6 medium-chain triglyceride used within the food, drug, and cosmetic industry. In both cases, there are reports of liquid-liquid extraction methods with organic solvents used to recover these compounds $[118,119]$. 
Table 2. Secondary metabolites produced by LAB compatible with a multi-product bioprocess.

\begin{tabular}{|c|c|c|c|c|c|c|}
\hline Metabolite & Titer & Microorganism & $\begin{array}{l}\text { Location within The } \\
\text { Fermentation }\end{array}$ & Biological Activity & Downstream & Reference \\
\hline 2,3 butanediol & $32 \mathrm{~g} / \mathrm{L}$ & Lactococcus lactis & Supernatant & $\begin{array}{l}\text { Bulk chemical in } \\
\text { plastic industry }\end{array}$ & $\begin{array}{l}\text { Distillation, stream stripping, } \\
\text { pervaporation }\end{array}$ & [120] \\
\hline $\begin{array}{l}\text { 2-pyrrolidone-5-carboxylic } \\
\text { acid (Pyroglutamic acid) }\end{array}$ & - & $\begin{array}{l}\text { Lactobacillus spp. Pediococcus } \\
\text { spp. }\end{array}$ & Supernatant & Antimicrobial & $\begin{array}{l}\text { Ethanol precipitation, gel } \\
\text { filtration, and anion exchange }\end{array}$ & [121] \\
\hline Azelaic acid & $2.71 \mathrm{mg} / \mathrm{L}$ & Leuconostoc citreum L123 & Supernatant & Antifungal & Organic extraction & [122] \\
\hline Bacteriocins & $0.72 \mathrm{~g} / \mathrm{L}$ & $\begin{array}{c}\text { Staphylococcus gallinarum and } S . \\
\text { epidermidis }\end{array}$ & Supernatant & Antimicrobial & $\begin{array}{l}\text { Salting-out, solvent extraction, } \\
\text { ultrafiltration, } \\
\text { adsorption-desorption, ion } \\
\text { exchange, and size exclusion } \\
\text { chromatography }\end{array}$ & {$[123,124]$} \\
\hline Caproic acid & $102 \mathrm{mg} / \mathrm{L}$ & Lactobacillus sanfrancisco $\mathrm{CB} 1$ & Supernatant & $\begin{array}{l}\text { Antimicrobial, } \\
\text { Flavor, and fuel } \\
\text { precursor }\end{array}$ & Organic extraction & [125] \\
\hline Conjugated linoleic acid & $40 \mathrm{~g} / \mathrm{L}$ & $\begin{array}{c}\text { Bifidobacterium spp., } \\
\text { Propionibacterium freudenreichii, } \\
\text { Lactobacillus plantarum AKU } \\
1009 \mathrm{a}\end{array}$ & $\begin{array}{l}\text { Intracellular or } \\
\text { cell-associated }\end{array}$ & $\begin{array}{c}\text { Reduces } \\
\text { carcinogenesis, } \\
\text { atherosclerosis, and } \\
\text { body fat }\end{array}$ & $\begin{array}{l}\text { Intracellular (or associated with } \\
\text { cells) and extracellular; urea } \\
\text { treatment after organic extraction }\end{array}$ & {$[116,117]$} \\
\hline Cyclic dipeptides & - & $\begin{array}{l}\text { Lactobacillus spp., Leuconostoc } \\
\text { spp., Weissella spp., and } \\
\text { Lactococcus lactis }\end{array}$ & Supernatant & Antiviral, antifungal & $\begin{array}{l}\text { Selective precipitation (ethanol, } \\
\text { trichloroacetic acid, or ammonium } \\
\text { sulfate); ultra and nano-filtration; } \\
\text { chromatographic methods. }\end{array}$ & [126-128] \\
\hline Diacetyl and acetoin & $\begin{array}{l}\text { DC } 3.5 \mathrm{mg} / \mathrm{L} \\
\text { AMC } 2.6 \mathrm{~g} / \mathrm{L}\end{array}$ & $\begin{array}{c}\text { Leuconostoc sp., } \\
\text { Streptococcus diacerylactis }\end{array}$ & Supernatant & Flavor and fragrance & $\begin{array}{c}\text { Distillation at } 86-87^{\circ} \mathrm{C} \text { and reactive } \\
\text { distillation }\end{array}$ & {$[129,130]$} \\
\hline Exopoly-saccharides & $5.12 \mathrm{~g} / \mathrm{L}$ & Lactobacillus acidophilus & Supernatant & $\begin{array}{c}\text { Antioxidant, } \\
\text { antibacterial, } \\
\text { antiulcer, antitumor, } \\
\text { immunostimulatory }\end{array}$ & Ethanol precipitation & [131] \\
\hline Lipoteichoic acid & - & $\begin{array}{l}\text { Staphylococcus aureus } \\
\text { Lactobacillus rhamosus GG }\end{array}$ & Cell-associated & Immunomodulator & $\begin{array}{l}\text { Organic extraction, hydrophobic } \\
\text { interaction, chromatography }\end{array}$ & {$[110,111]$} \\
\hline $\begin{array}{l}\text { Mevalonic acid } \\
\text { Mevalonolactone }\end{array}$ & - & $\begin{array}{l}\text { Lactobacillus plantarum VTT } \\
\text { E-78076 }\end{array}$ & Supernatant & Antifungal & Ultra and nano-filtration & [132] \\
\hline $\begin{array}{c}\text { Phenyl lactic and } \\
p \text {-hydroxyphenyl acetic acid }\end{array}$ & - & $\begin{array}{l}\text { Lactobacillus plantarum strain } \\
21 \mathrm{~B}\end{array}$ & Supernatant & Antifungal & Ultra and nano-filtration & [133] \\
\hline $\begin{array}{c}\text { Reuterin } \\
\text { (3-hydroxypropionaldehyde) }\end{array}$ & $8 \mathrm{mg} / \mathrm{L}$ & Lactobacillus reuteri & Supernatant & Antimicrobial & $\begin{array}{l}\text { Alcoholic extraction, organic } \\
\text { extraction, size filtration, and ion } \\
\text { exchange; distillation }\end{array}$ & {$[133,134]$} \\
\hline $\begin{array}{c}\text { Sweeteners (mannitol, } \\
\text { tagatose, sorbitol, trehalose) }\end{array}$ & - & & Supernatant & Food industry & $\begin{array}{l}\text { Ultra and nano-filtration, } \\
\text { chromatographic methods }\end{array}$ & [135] \\
\hline Vitamins (B-group) & - & & Supernatant & Food supplement & $\begin{array}{l}\text { Ultra and nano-filtration, } \\
\text { chromatographic methods }\end{array}$ & {$[136,137]$} \\
\hline
\end{tabular}


During fermentation, exopolysaccharides (EPS) are liberated. These compounds are branched polymers of sugars (or derivatives) with commercial value due to their properties as food texturizers and their health-promoting attributes $[80,81,138]$. EPS precipitate via the addition of ethanol, but the use of this solvent is not compatible with the LA downstream process since concentration of this solvent may increase total operational volumes. Nevertheless, during filtration and ultrafiltration steps, LA remains in the permeate and EPS are retained in a solution with a lower volume. At this point, EPS purification via ethanol precipitation would be possible [139]. Depending on their properties, some cyclic dipeptides could be purified following the same approach [128], as well as 2-pyrrolidone-5-carboxylic acid (used as a humectant for dry skin and hair products) [121]. Other polar molecules such as sugars, small organic acids, and vitamins follow the same purification path as LA, and chromatographic methods would be necessary to separate them $[132,135,136]$.

The final step in a LA downstream process is distillation, which is basically used to eliminate water from the final LA solution. Volatile compounds produced by LAB, e.g., reuterin and diacetyl (DC), can be recovered via distillation at $78-82$ and $86-87^{\circ} \mathrm{C}$, respectively. Reuterin is a potent antimicrobial, and DC is used as a food and beverage supplement due to its characteristic butter flavor. Acetoin, the precursor of DC, can be recovered as well after an enzymatic transformation into DC. In this sense, the addition of a reactive distillation step would be useful in order to recover both compounds and to eliminate acetoin from the supernatant.

As mentioned before, there are several options in which an LA production/purification process can be combined with the recovery of other high-value compounds that are normally discarded within the downstream process. Key points or challenges remain in the combination of the fermentation and downstream process in such a way that production of all the compounds is sustainable.

\section{Perspectives of Multi-Product Processes}

Many research efforts focused on the development of green processes orientated toward the production of organic chemicals via biorefinery or white biotechnology by using carbohydrate sources such as corn syrup [1,140-142]. However, alternative energy sources, e.g., agro-industrial by-products and other solid food waste, were extensively evaluated for the production of these compounds, which are normally used in the automobile, textile, pharmaceutical, beverage and food, plastic, and many more industries [1,140-144]. Such processes are possible because agro-industrial by-products not only serve as a carbohydrate source but also provide extra nutrients, i.e., amino acids, vitamins, and minerals. One of the most important reasons for using by-products is that these materials do not compete for arable land with grain crops cultivated for human feed [145]. As mentioned before, some metabolites obtained from green processes are lactic, succinic, and 2,3-butanediollactic acids, fructo-oligosaccharides, bioethanol, biodiesel, bioactive peptides, enzymes, volatile compounds, and many more $[1,140,141]$. In parallel, current rigorous regulations regarding the application of by-products together with the demand for renewable compounds and fuels are forcing the manufacturing industry toward more cost-effective processes while meeting customer demand [142].

Regardless of the microorganism used, white biotechnological processes are traditionally developed and optimized based on a specific-metabolite pathway involving selected starter cultures or microbial consortia [140]. Although this approach proved to be very successful in the production of specific metabolites such as L-(+)-LA, researchers constantly search for bacterial mechanisms focused on the use of potential by-products to simultaneously produce more than one bio-product, while enhancing the effectiveness of the process [146]. An example of a multi-product process was recently reported by Nguyen et al. [146]; they proposed an integrated process for economical high-yield production of $\mathrm{D}$-mannose and bioethanol from a coffee residue. This process involves pretreatment, enzymatic hydrolysis, fermentation, recuperation, and purification steps which can be performed using environmentally friendly technologies [146].

From a technological point of view, efforts focused on the production of metabolites may employ the so-called "reverse food engineering" strategy, comprising at least five main steps: (i) isolation of LAB 
species, (ii) DNA screening of LAB for the ability to release the metabolites of interest, (iii) exploitation of the best metabolite's producer strain for innovation in multi-product processes, (iv) development of extraction, separation, and purification process of each metabolite, and (v) an industry interested in the implementation of the process once the economic feasibility is proven [140]. Furthermore, the best conditions to produce one metabolite may not be necessarily the best environment for the synthesis of another metabolite; therefore, the overall effectiveness of the process may be compromised. When all these steps are clear, it is necessary to construct a cell factory for an efficient refining platform to produce a variety of natural products from bacteria. Therefore, many studies must be done to define the conditions allowing a balanced multi-product process.

In the case of LA, a potential valorization of the process could be achieved via the utilization of different streams obtained during the downstream process (Figure 3).

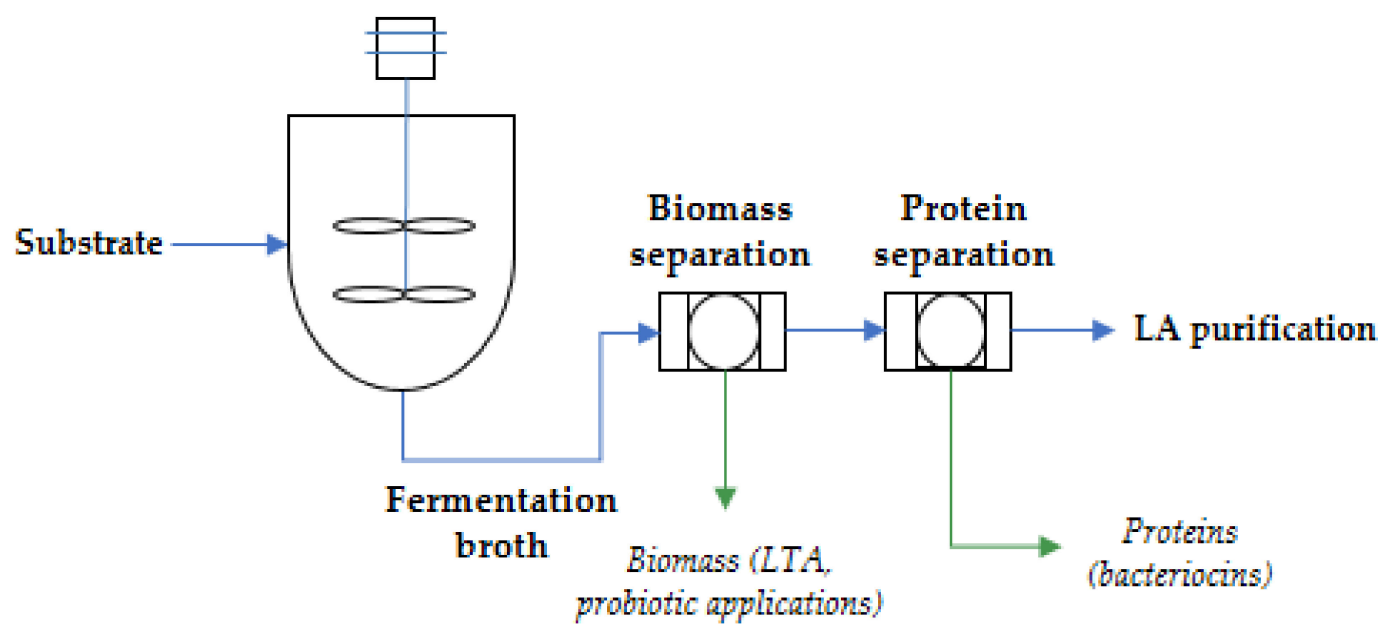

Figure 3. Potential process flow diagram for of a multi-product LAB based process (adapted from Reference [147] licensed under CC BY-NC 4.0 available at https://doi.org/10.1016/j.jclepro.2019.119165).

\section{Conclusions}

Recently, circular bioeconomy emerged, and it is expected to continually evolve, driven by sustainability challenges, e.g., expanding population, resource depletion, and climate change [148]. Its concurrence with technological processes, in addition to economic and environmental assessments, strongly motivates the industry to consider bio-based chemical production as an attractive area for investment. In concordance with this, biorefineries should integrate processes to facilitate the complete fractionation and the valorization of all biomass components [148,149]. The creation of multi-product integrated processes is a key aspect to favor the research, development, and industrial implementation.

Lactic acid bacteria are proposed as some of the most promising microorganisms for the transformation of biomass into valuable industrial products. LA is a very versatile biotechnological molecule which plays an important role as an intermediate metabolite to produce many products of interest [150]. In addition to LA, several products with interesting characteristics can be obtained from LAB fermentation such as bacteriocins, probiotics, and LTA. However, the titers for these secondary products are not yet optimized. Nevertheless, they hold potential and market significance, which could enhance the value of traditional LA fermentation. Further investigation toward a successful co-production of LA and other metabolites of interest could in fact pave the way for the establishment of sustainable and more efficient multi-product bioprocesses.

Author Contributions: Conceptualization, J.A.M.-V. and J.P.L.-G.; review and editing, J.A.M.-V., N.B., M.R.-S., C.R.-G., J.U., and J.P.L.-G.; writing—original draft preparation, M.R.-S., J.M.-Z., N.B., C.R.-G., L.S., A.O.-W., J.U., J.A.M.-V., and J.P.L.-G. All authors have read and agreed to the published version of the manuscript.

Funding: This research was funded by the Consejo Nacional de Rectores, Costa Rica (CONARE), grant number DFG-003-2019, and the Deutsche Forschungsgemeinschaft, Germany (DFG). Grant number LO 1999/1-1. 
Conflicts of Interest: The authors declare no conflicts of interest.

\section{References}

1. Qiu, Y.; Lei, P.; Zhang, Y.; Sha, Y.; Zhan, Y.; Xu, Z.; Li, S.; Xu, H.; Ouyang, P. Recent advances in bio-based multi-products of agricultural Jerusalem artichoke resources. Biotechnol. Biofuels 2018, 11, 151. [CrossRef] [PubMed]

2. Zondervan, E.; Nawaz, M.; de Haan, A.B.; Woodley, J.M.; Gani, R. Optimal design of a multi-product biorefinery system. Comput. Chem. Eng. 2011, 35, 1752-1766. [CrossRef]

3. Santos, F. Sugarcane Biorefinery, Technology and Perspectives, 1st ed.; Academic Press: London, UK, 2020.

4. Kamm, B.; Kamm, M. Biorefineries-Multi product processes. Adv. Biochem. Eng. Biotechnol. 2006, 105, 175-204.

5. Mazzoli, R.; Bosco, F.; Mizrahi, I.; Bayer, E.A.; Pessione, E. Towards lactic acid bacteria-based biorefineries. Biotechnol. Adv. 2014, 32, 1216-1236. [CrossRef] [PubMed]

6. Vinderola, G.; Ouwehand, A.C.; Salminen, S.; von Wright, A. Lactic Acid Bacteria: Microbiological and Functional Aspects, 5th ed.; CRC Press: Boca Raton, FL, USA, 2019.

7. Salvetti, E.; Harris, H.M.B.; Felis, G.E.; O’Toole, P.W. Comparative genomics of the genus Lactobacillus reveals robust phylogroups that provide the basis for reclassification. Appl. Environ. Microbiol. 2018, 84. [CrossRef]

8. Endo, A.; Tanizawa, Y.; Arita, M. Isolation and identification of lactic acid bacteria from environmental samples. In Methods in Molecular Biology; Humana Press: New York, NY, USA, 2019; pp. 3-13.

9. Sabatini, N. A Comparison of the Volatile Compounds, in Spanish-style, Greek-style and Castelvetrano-style Green Olives of the Nocellara del Belice Cultivar: Alcohols, Aldehydes, Ketones, Esters and Acids. In Olives and Olive Oil in Health and Disease Prevention; Elsevier Inc.: Burlington, VT, USA, 2010; pp. 219-231.

10. Ruiz Rodríguez, L.G.; Mohamed, F.; Bleckwedel, J.; Medina, R.; De Vuyst, L.; Hebert, E.M.; Mozzi, F. Diversity and functional properties of lactic acid bacteria isolated from wild fruits and flowers present in northern Argentina. Front. Microbiol. 2019, 10. [CrossRef]

11. Ghaffar, T.; Irshad, M.; Anwar, Z.; Aqil, T.; Zulifqar, Z.; Tariq, A.; Kamran, M.; Ehsan, N.; Mehmood, S. Recent trends in lactic acid biotechnology: A brief review on production to purification. J. Radiat. Res. Appl. Sci. 2014, 7, 222-229. [CrossRef]

12. Champagne, C.P. The lactic acid bacteria. Int. Dairy J. 1994, 4, 665-666. [CrossRef]

13. Börner, R.A.; Kandasamy, V.; Axelsen, A.M.; Nielsen, A.T.; Bosma, E.F. Genome editing of lactic acid bacteria: Opportunities for food, feed, pharma and biotech. FEMS Microbiol. Lett. 2019, 366, i30-i41. [CrossRef]

14. Van Pijkeren, J.-P.; Barrangou, R. Genome Editing of Food-Grade Lactobacilli To Develop Therapeutic Probiotics. Microbiol. Spectr. 2017, 5. [CrossRef]

15. Barrangou, R.; Horvath, P. CRISPR: New Horizons in Phage Resistance and Strain Identification. Annu. Rev. Food Sci. Technol. 2012, 3, 143-162. [CrossRef] [PubMed]

16. Duar, R.M.; Lin, X.B.; Zheng, J.; Martino, M.E.; Grenier, T.; Pérez-Muñoz, M.E.; Leulier, F.; Gänzle, M.; Walter, J. Lifestyles in transition: Evolution and natural history of the genus Lactobacillus. FEMS Microbiol. Rev. 2017, 41, S27-S48. [CrossRef] [PubMed]

17. Sadiq, F.A.; Yan, B.; Tian, F.; Zhao, J.; Zhang, H.; Chen, W. Lactic Acid Bacteria as Antifungal and Anti-Mycotoxigenic Agents: A Comprehensive Review. Compr. Rev. Food Sci. Food Saf. 2019, 18, 1403-1436. [CrossRef]

18. Rahbar Saadat, Y.; Yari Khosroushahi, A.; Pourghassem Gargari, B. A comprehensive review of anticancer, immunomodulatory and health beneficial effects of the lactic acid bacteria exopolysaccharides. Carbohydr. Polym. 2019, 217, 79-89. [CrossRef] [PubMed]

19. Venegas-Ortega, M.G.; Flores-Gallegos, A.C.; Martínez-Hernández, J.L.; Aguilar, C.N.; Nevárez-Moorillón, G.V. Production of Bioactive Peptides from Lactic Acid Bacteria: A Sustainable Approach for Healthier Foods. Compr. Rev. Food Sci. Food Saf. 2019, 18, 1039-1051. [CrossRef]

20. Russo, P.; Spano, G.; Capozzi, V. Safety evaluation of starter cultures. In Starter Cultures in Food Production; John Wiley \& Sons, Ltd.: Chichester, UK, 2017; pp. 101-128. 
21. Vinusha, K.S.; Deepika, K.; Johnson, T.S.; Agrawal, G.K.; Rakwal, R. Proteomic studies on lactic acid bacteria: A review. Biochem. Biophys. Rep. 2018, 14, 140-148. [CrossRef]

22. Kim, A.R.; Ahn, K.B.; Yun, C.H.; Park, O.J.; Perinpanayagam, H.; Yoo, Y.J.; Kum, K.Y.; Han, S.H. Lactobacillus plantarum Lipoteichoic Acid Inhibits Oral Multispecies Biofilm. J. Endod. 2019, 45, 310-315. [CrossRef]

23. Lebeer, S.; Claes, I.J.J.J.; Vanderleyden, J. Anti-inflammatory potential of probiotics: Lipoteichoic acid makes a difference. Trends Microbiol. 2012, 20,5-10. [CrossRef]

24. Ryu, Y.H.; Baik, J.E.; Yang, J.S.; Kang, S.S.; Im, J.; Yun, C.H.; Kim, D.W.; Lee, K.; Chung, D.K.; Ju, H.R.; et al. Differential immunostimulatory effects of Gram-positive bacteria due to their lipoteichoic acids. Int. Immunopharmacol. 2009, 9, 127-133. [CrossRef]

25. Pinu, F.R.; Villas-Boas, S.G. Extracellular microbial metabolomics: The state of the art. Metabolites 2017, 7, 43. [CrossRef]

26. Gou, M.; Song, W. The growing U.S. bioeconomy: Drivers, development and constraints. N. Biotechnol. 2019, 49, 48-57. [CrossRef]

27. Castro-Aguirre, E.; Iñiguez-Franco, F.; Samsudin, H.; Fang, X.; Auras, R. Poly(lactic acid)—Mass production, processing, industrial applications, and end of life. Adv. Drug Deliv. Rev. 2016, 107, 333-366. [CrossRef] [PubMed]

28. Kuo, Y.C.; Yuan, S.F.; Wang, C.A.; Huang, Y.J.; Gou, G.L.; Hwang, W.S. Production of optically pure 1-lactic acid from lignocellulosic hydrolysate by using a newly isolated and d-lactate dehydrogenase gene-deficient Lactobacillus paracasei strain. Bioresour. Technol. 2015, 198, 651-657. [CrossRef] [PubMed]

29. Villadsen, J. Innovative technology to meet the demands of the white biotechnology revolution of chemical production. Chem. Eng. Sci. 2007, 62, 6957-6968. [CrossRef]

30. Wang, Y.; Yang, Z.; Qin, P.; Tan, T. Fermentative 1-(+)-lactic acid production from defatted rice bran. RSC Adv. 2014, 4, 8907-8913. [CrossRef]

31. Abdel-Rahman, M.A.; Tashiro, Y.; Zendo, T.; Sonomoto, K. Improved lactic acid productivity by an open repeated batch fermentation system using Enterococcus mundtii QU 25. RSC Adv. 2013, 3, 8437-8445. [CrossRef]

32. Abdel-Rahman, M.A.; Xiao, Y.; Tashiro, Y.; Wang, Y.; Zendo, T.; Sakai, K.; Sonomoto, K. Fed-batch fermentation for enhanced lactic acid production from glucose/xylose mixture without carbon catabolite repression. $J$. Biosci. Bioeng. 2015, 119, 153-158. [CrossRef]

33. Wang, Y.; Abdel-Rahman, M.A.; Tashiro, Y.; Xiao, Y.; Zendo, T.; Sakai, K.; Sonomotes, K. L-(+)-Lactic acid production by co-fermentation of cellobiose and xylose without carbon catabolite repression using Enterococcus mundtii QU 25. RSC Adv. 2014, 4, 22013-22021. [CrossRef]

34. Wee, Y.J.; Yun, J.S.; Park, D.H.; Ryu, H.W. Biotechnological production of L(+)-lactic acid from wood hydrolyzate by batch fermentation of Enterococcus faecalis. Biotechnol. Lett. 2004, 26, 71-74. [CrossRef]

35. Wee, Y.J.; Kim, J.N.; Yun, J.S.; Ryu, H.W. Utilization of sugar molasses for economical L(+)-lactic acid production by batch fermentation of Enterococcus faecalis. Enzyme. Microb. Technol. 2004, 35, 568-573. [CrossRef]

36. Subramanian, M.R.; Talluri, S.; Christopher, L.P. Production of lactic acid using a new homofermentative Enterococcus faecalis isolate. Microb. Biotechnol. 2015, 8, 221-229. [CrossRef] [PubMed]

37. Yuan, S.F.; Hsu, T.C.; Wang, C.A.; Jang, M.F.; Kuo, Y.C.; Alper, H.S.; Guo, G.L.; Hwang, W.S. Production of optically pure $1(+)$-lactic acid from waste plywood chips using an isolated thermotolerant Enterococcus faecalis SI at a pilot scale. J. Ind. Microbiol. Biotechnol. 2018, 45, 961-970. [CrossRef] [PubMed]

38. Wee, Y.J.; Kim, H.O.; Yun, J.S.; Ryw, H.W. Pilot-scale lactic acid production via batch culturing of Lactobacillus sp. RKY2 using corn steep liquor as a nitrogen source. Food Technol. Biotechnol. 2006, 44, 293-298.

39. Yi, X.; Zhang, P.; Sun, J.; Tu, Y.; Gao, Q.; Zhang, J.; Bao, J. Engineering wild-type robust Pediococcus acidilactici strain for high titer l- and d-lactic acid production from corn stover feedstock. J. Biotechnol. 2016, 217, 112-121. [CrossRef] [PubMed]

40. Hama, S.; Mizuno, S.; Kihara, M.; Tanaka, T.; Ogino, O.; Noda, H.; Kondo, A. Production of d-lactic acid from hardwood pulp by mechanical milling followed by simultaneous saccharification and fermentation using metabolically engineered Lactobacillus plantarum. Bioresour. Technol. 2015, 187, 167-172. [CrossRef] 
41. Sauer, M.; Porro, D.; Mattanovich, D.; Branduardi, P. 16 years research on lactic acid production with yeast-ready for the market? Biotechnol. Genet. Eng. Rev. 2010, 27, 229-256. [CrossRef]

42. Yamada, R.; Wakita, K.; Mitsui, R.; Ogino, H. Enhanced d-lactic acid production by recombinant Saccharomyces cerevisiae following optimization of the global metabolic pathway. Biotechnol. Bioeng. 2017, 114, 2075-2084. [CrossRef]

43. Baek, S.H.; Kwon, E.Y.; Bae, S.J.; Cho, B.R.; Kim, S.Y.; Hahn, J.S. Improvement of d-Lactic Acid Production in Saccharomyces cerevisiae Under Acidic Conditions by Evolutionary and Rational Metabolic Engineering. Biotechnol. J. 2017, 12. [CrossRef]

44. Baek, S.H.; Kwon, E.Y.; Kim, Y.H.; Hahn, J.S. Metabolic engineering and adaptive evolution for efficient production of D-lactic acid in Saccharomyces cerevisiae. Appl. Microbiol. Biotechnol. 2016, 100, 2737-2748. [CrossRef]

45. López-Gómez, J.P.; Alexandri, M.; Schneider, R.; Venus, J. A review on the current developments in continuous lactic acid fermentations and case studies utilising inexpensive raw materials. Process Biochem. 2019, 79, 1-10. [CrossRef]

46. Lee, R.K.; Ryu, H.W.; Oh, H.; Kim, M.; Wee, Y.J. Cell-recycle continuous fermentation of Enterococcus faecalis RKY1 for economical production of lactic acid by reduction of yeast extract supplementation. J. Microbiol. Biotechnol. 2014, 24, 661-666. [CrossRef] [PubMed]

47. Abdel-Rahman, M.A.; Tashiro, Y.; Zendo, T.; Sakai, K.; Sonomoto, K. Highly efficient L-lactic acid production from xylose in cell recycle continuous fermentation using Enterococcus mundtii QU 25. RSC Adv. 2016, 6, 17659-17668. [CrossRef]

48. Kwon, S.; Yoo, I.K.; Lee, W.G.; Chang, H.N.; Chang, Y.K. High-rate continuous production of lactic acid by Lactobacillus rhamnosus in a two-stage membrane cell-recycle bioreactor. Biotechnol. Bioeng. 2001, 73, 25-34. [CrossRef]

49. Wee, Y.J.; Ryu, H.W. Lactic acid production by Lactobacillus sp. RKY2 in a cell-recycle continuous fermentation using lignocellulosic hydrolyzates as inexpensive raw materials. Bioresour. Technol. 2009, 100, 4262-4270. [CrossRef] [PubMed]

50. Melzoch, K.; Votruba, J.; Hábová, V.; Rychtera, M. Lactic acid production in a cell retention continuous culture using lignocellulosic hydrolysate as a substrate. J. Biotechnol. 1997, 56, 25-31. [CrossRef]

51. Zhang, J.; Hao, N.; Chen, G.Q. Effect of expressing polyhydroxybutyrate synthesis genes (phbCAB) in Streptococcus zooepidemicus on production of lactic acid and hyaluronic acid. Appl. Microbiol. Biotechnol. 2006, 71, 222-227. [CrossRef]

52. Demichelis, F.; Pleissner, D.; Fiore, S.; Mariano, S.; Navarro, I.M.; Schneider, R.; Venus, J. Investigation of food waste valorization through sequential lactic acid fermentative production and anaerobic digestion of fermentation residues. Bioresour. Technol. 2017, 241, 508-516. [CrossRef]

53. Schiraldi, C.; Adduci, V.; Valli, V.; Maresca, C.; Giuliano, M.; Lamberti, M.; Carteni, M.; de Rosa, M. High cell density cultivation of probiotics and lactic acid production. Biotechnol. Bioeng. 2003, 82, 213-222. [CrossRef]

54. Djukić-Vuković, A.P.; Mojović, L.V.; Vukašinović-Sekulić, M.S.; Nikolić, S.B.; Pejin, J.D. Integrated production of lactic acid and biomass on distillery stillage. Bioprocess Biosyst. Eng. 2013, 36, 1157-1164. [CrossRef]

55. Djukić-Vuković, A.P.; Mojović, L.V.; Semenčenko, V.V.; Radosavljević, M.M.; Pejin, J.D.; Kocić-Tanackov, S.D. Effective valorisation of distillery stillage by integrated production of lactic acid and high quality feed. Food Res. Int. 2015, 73, 75-80. [CrossRef]

56. Djukić-Vuković, A.P.; Jokić, B.M.; Kocić-Tanackov, S.D.; Pejin, J.; Mojović, L.V. Mg-modified zeolite as a carrier for Lactobacillus rhamnosus in $\mathrm{L}(+)$ lactic acid production on distillery wastewater. J. Taiwan Inst. Chem. Eng. 2016, 59, 262-266. [CrossRef]

57. Cui, F.; Wan, C.; Li, Y.; Liu, Z.; Rajashkara, G. Co-production of Lactic Acid and Lactobacillus rhamnosus Cells from Whey Permeate with Nutrient Supplements. Food Bioprocess Technol. 2012, 5, 1278-1286. [CrossRef]

58. De Vuyst, L.; Leroy, F. Bacteriocins from lactic acid bacteria: Production, purification, and food applications. J. Mol. Microbiol. Biotechnol. 2007, 13, 194-199. [CrossRef] [PubMed]

59. Chen, H.; Hoover, D. Bacteriocins and their Food Applications. Compr. Rev. Food Sci. Food Saf. 2003, 2, 82-100. [CrossRef]

60. Cheigh, C.I.; Choi, H.J.; Park, H.; Kim, S.B.; Kook, M.C.; Kim, T.S.; Hwang, J.K.; Pyun, Y.R. Influence of growth conditions on the production of a nisin-like bacteriocin by Lactococcus lactis subsp. lactis A164 isolated from kimchi. J. Biotechnol. 2002, 95, 225-235. [CrossRef] 
61. Neysens, P.; Messens, W.; De Vuyst, L. Effect of sodium chloride on growth and bacteriocin production by Lactobacillus amylovorus DCE 471. Int. J. Food Microbiol. 2003, 88, 29-39. [CrossRef]

62. Callewaert, R.; De Vuyst, L. Bacteriocin production with Lactobacillus amylovorus DCE 471 is improved and stabilized by fed-batch fermentation. Appl. Environ. Microbiol. 2000, 66, 606-613. [CrossRef]

63. Parente, E.; Brienza, C.; Ricciardi, A.; Addario, G. Growth and bacteriocin production by Enterococcus faecium DPC1146 in batch and continuous culture. J. Ind. Microbiol. Biotechnol. 1997, 18, 62-67. [CrossRef]

64. Avonts, L.; Van Uytven, E.; De Vuyst, L. Cell growth and bacteriocin production of probiotic Lactobacillus strains in different media. Int. Dairy J. 2004, 14, 947-955. [CrossRef]

65. Todorov, S.D.; van Reenan, C.A.; Dicks, L.M.T. Optimization of bacteriocin production by Lactobacillus plantarum ST13BR, a strain isolated from barley beer. J. Gen. Appl. Microbiol. 2004, 50, 149-157. [CrossRef]

66. Todorov, S.D.; Dicks, L.M.T. Effect of medium components on bacteriocin production by Lactobacillus pentosus ST151BR, a strain isolated from beer produced by the fermentation of maize, barley and soy flour. World J. Microbiol. Biotechnol. 2004, 20, 643-650. [CrossRef]

67. Malheiros, P.S.; Sant'Anna, V.; Todorov, S.D.; Franco, B.D.G.M. Optimization of growth and bacteriocin production by Lactobacillus sakei subsp. Sakei 2a. Braz. J. Microbiol. 2015, 46, 825-834. [CrossRef] [PubMed]

68. Ogunbanwo, S.T.; Sanni, A.I.; Onilude, A.A. Influence of cultural conditions on the production of bacteriocin by Lactobacillus brevis OG1. Afr. J. Biotechnol. 2003, 2, 182-192.

69. Lejeune, R.; Callewaert, R.; Crabbé, K.; De Vuyst, L. Modelling the growth and bacteriocin production by Lactobacillus amylovorus DCE 471 in batch cultivation. J. Appl. Microbiol. 1998, 84, 159-168. [CrossRef]

70. Todorov, S.; Gotcheva, B.; Dousset, X.; Onno, B.; Ivanova, I. Influence of growth medium on bacteriocin production in Lactobacillus plantarum st31. Biotechnol. Biotechnol. Equip. 2000, 14, 50-55. [CrossRef]

71. Zamfir, M.; Callewaert, R.; Cornea, P.C.; De Vuyst, L. Production kinetics of acidophilin 801, a bacteriocin produced by Lactobacillus acidophilus IBB 801. FEMS Microbiol. Lett. 2000, 190, 305-308. [CrossRef]

72. Messens, W.; Neysens, P.; Vansieleghem, W.; Vanderhoeven, J.; De Vuyst, L. Modeling growth and bacteriocin production by Lactobacillus amylovorus DCE 471 in response to temperature and $\mathrm{pH}$ values used for sourdough fermentations. Appl. Environ. Microbiol. 2002, 68, 1431-1435. [CrossRef]

73. Li, C.; Bai, J.; Cai, Z.; Ouyang, F. Optimization of a cultural medium for bacteriocin production by Lactococcus lactis using response surface methodology. J. Biotechnol. 2002, 93, 27-34. [CrossRef]

74. Da Luz, J.A.; Hans, E.; Zeng, A.-P. Automated fast filtration and on-filter quenching improve the intracellular metabolite analysis of microorganisms. Eng. Life Sci. 2014, 14, 135-142. [CrossRef]

75. Hill, C.; Guarner, F.; Reid, G.; Gibson, G.R.; Merenstein, D.J.; Pot, B.; Morelli, L.; Canani, R.B.; Flint, H.J.; Salminen, S.; et al. Expert consensus document: The international scientific association for probiotics and prebiotics consensus statement on the scope and appropriate use of the term probiotic. Nat. Rev. Gastroenterol. Hepatol. 2014, 11, 506-514. [CrossRef]

76. Kumar, H.; Salminen, S.; Verhagen, H.; Rowland, I.; Heimbach, J.; Bañares, S.; Young, T.; Nomoto, K.; Lalonde, M. Novel probiotics and prebiotics: Road to the market. Curr. Opin. Biotechnol. 2015, 32, 99-103. [CrossRef] [PubMed]

77. Aleixandre-Tudó, J.L.; Castelló-Cogollos, L.; Aleixandre, J.L.; Aleixandre-Benavent, R. Tendencies and Challenges in Worldwide Scientific Research on Probiotics. Probiotics Antimicrob. Proteins 2019. [CrossRef] [PubMed]

78. Ouwehand, A.C.; Salminen, S.; Isolauri, E. Probiotics: An overview of beneficial effects. Antonie van Leeuwenhoek. Int. J. Gen. Mol. Microbiol. 2002, 82, 279-289. [CrossRef]

79. Leahy, S.C.; Higgins, D.G.; Fitzgerald, G.F.; Van Sinderen, D. Getting better with bifidobacteria. J. Appl. Microbiol. 2005, 98, 1303-1315. [CrossRef]

80. Pérez-Ramos, A.; Mohedano, M.L.; López, P.; Spano, G.; Fiocco, D.; Russo, D.; Capozzi, V. In situ $\beta$-glucan fortification of cereal-based matrices by Pediococcus parvulus 2.6, Technological aspects and prebiotic potential. Int. J. Mol. Sci. 2017, 18, 1588. [CrossRef]

81. Deo, D.; Davray, D.; Kulkarni, R.A. Diverse repertoire of exopolysaccharide biosynthesis gene clusters in Lactobacillus revealed by comparative analysis in 106 sequenced genomes. Microorganisms 2019, 7, 444. [CrossRef] 
82. Lolou, V.; Panayiotidis, M.I. Functional role of probiotics and prebiotics on skin health and disease. Fermentation 2019, 5, 41. [CrossRef]

83. Mattila-Sandholm, T.; Myllärinen, P.; Crittenden, R.; Mogensen, G.; Fondén, R.; Saarela, M. Technological challenges for future Probiotic foods. Int. Dairy J. 2002, 12, 173-182. [CrossRef]

84. Plessas, S.; Bosnea, L.; Alexopoulus, A.; Bezirtzoglou, E. Potenctial effects of probiotics in cheese and yogurt production: A review. Eng. Life Sci. 2012, 12, 433-440. [CrossRef]

85. Rivière, A.; Selak, M.; Lantin, D.; Leroy, F.; De Vuyst, L. Bifidobacteria and butyrate-producing colon bacteria: Importance and strategies for their stimulation in the human gut. Front. Microbiol. 2016, 7, 979. [CrossRef]

86. Fiocco, D.; Longo, A.; Arena, M.P.; Russo, P.; Spano, G.; Capozzi, V. How probiotics face food stress: They get by with a little help. Crit. Rev. Food Sci. Nutr. 2019, 1-29. [CrossRef] [PubMed]

87. Sanders, M.E.; Merenstein, D.J.; Reid, G.; Gibson, G.R.; Rastall, R.A. Probiotics and prebiotics in intestinal health and disease: From biology to the clinic. Nat. Rev. Gastroenterol. Hepatol. 2019, 16, 605-616. [CrossRef] [PubMed]

88. Todorov, S.D.; LeBlanc, J.G.; Franco, B.D.G.M. Evaluation of the probiotic potential and effect of encapsulation on survival for Lactobacillus plantarum ST16Pa isolated from papaya. World J. Microbiol. Biotechnol. 2012, 28, 973-984. [CrossRef] [PubMed]

89. Puebla-Barragan, S.; Reid, G. Forty-five-year evolution of probiotic therapy. Microb. Cell 2019, 6, 184-196. [CrossRef] [PubMed]

90. Emerenini, E.; Afolabi, O.R.; Okolie, P.I.; Akintokun, A.K. Isolation and Molecular Characterization of Lactic Acid Bacteria Isolated from Fresh Fruits and Vegetables Using Nested PCR Analysis. Br. Microbiol. Res. J. 2013, 3, 368-377. [CrossRef]

91. Moraes, P.M.; Martins Perin, L.; Silva Júnior, A.; Nero, L.A. Comparison of phenotypic and molecular tests to identify lactic acid bacteria. Braz. J. Microbiol. 2013, 44, 109-112. [CrossRef]

92. Castillo, N.A.; Perdigán, G.; De Moreno De Leblanc, A. Oral administration of a probiotic Lactobacillus modulates cytokine production and TLR expression improving the immune response against Salmonella enterica serovar Typhimurium infection in mice. BMC Microbiol. 2011, 11. [CrossRef]

93. García-Ruiz, A.; González de Llano, D.; Esteban-Fernández, A.; Requena, T.; Bartolomé, B.; Moreno-Arribas, M.V. Assessment of probiotic properties in lactic acid bacteria isolated from wine. Food Microbiol. 2014, 44, 220-225. [CrossRef]

94. Dlamini, Z.C.; Langa, R.L.S.; Aiyegoro, O.A.; Okoh, A.I. Safety Evaluation and Colonisation Abilities of Four Lactic Acid Bacteria as Future Probiotics. Probiotics Antimicrob. Proteins 2019, 11, 397-402. [CrossRef]

95. Mathara, J.M.; Schillinger, U.; Kutima, P.M.; Mbugua, S.K.; Guigas, C.; Franz, C.; Holzapfel, W.H. Functional properties of Lactobacillus plantarum strains isolated from Maasai traditional fermented milk products in Kenya. Curr. Microbiol. 2008, 56, 315-321. [CrossRef]

96. Evivie, S.E.; Huo, G.C.; Igene, J.O.; Bian, X. Some current applications, limitations and future perspectives of lactic acid bacteria as probiotics. Food Nutr. Res. 2017, 61, 1318034. [CrossRef] [PubMed]

97. Lee, Y.K.; Salminen, S. The coming of age of probiotics. Trends Food Sci. Technol. 1995, 6, 241-245. [CrossRef]

98. Klewicki, R.; Klewicka, E. Antagonistic activity of lactic acid bacteria as probiotics against selected bacteria of the Enterobaceriacae family in the presence of polyols and their galactosyl derivatives. Biotechnol. Lett. 2004, 26, 317-320. [CrossRef] [PubMed]

99. Gad, M.; Ravn, P.; Søborg, D.A.; Lund-Jensen, K.; Ouwehand, A.C.; Jensen, S.S. Regulation of the IL-10/IL-12 axis in human dendritic cells with probiotic bacteria. FEMS Immunol. Med. Microbiol. 2011, 63, 93-107. [CrossRef]

100. Haghighi, H.R.; Gong, J.; Gyles, C.L.; Hayes, M.A.; Sanei, B.; Parvizi, P.; Gisavi, H.; Chambers, J.R.; Sharif, S. Modulation of antibody-mediated immune response by probiotics in chickens. Clin. Diagn. Lab. Immunol. 2005, 12, 1387-1392. [CrossRef]

101. Frank, D.N.; St Amand, A.L.; Feldman, R.A.; Boedeker, E.C.; Harpaz, N.; Pace, N.R. Molecular-phylogenetic characterization of microbial community imbalances in human inflammatory bowel diseases. Proc. Natl. Acad. Sci. USA 2007, 104, 13780-13785. [CrossRef]

102. Özdemir, Ö. Various effects of different probiotic strains in allergic disorders: An update from laboratory and clinical data. Clin. Exp. Immunol. 2010, 160, 295-304. [CrossRef] 
103. Malanovic, N.; Lohner, K. Gram-positive bacterial cell envelopes: The impact on the activity of antimicrobial peptides. Biochim. Biophys. Acta Biomembr. 2016, 1858, 936-946. [CrossRef]

104. Kusumoto, S.; Fukase, K.; Fujimoto, Y. Synthesis of Lipopolysaccharide, Peptidoglycan, and Lipoteichoic Acid Fragments. In Comprehensive Glycoscience: From Chemistry to Systems Biology; Elsevier Inc.: Burlington, VT, USA, 2007; pp. 685-711.

105. Reichmann, N.T.; Gründling, A. Location, synthesis and function of glycolipids and polyglycerolphosphate lipoteichoic acid in Gram-positive bacteria of the phylum Firmicutes. FEMS Microbiol. Lett. 2011, 319, 97-105. [CrossRef]

106. Brown, S.; Santa Maria, J.P.; Walker, S. Wall Teichoic Acids of Gram-Positive Bacteria. Annu. Rev. Microbiol. 2013, 67, 313-336. [CrossRef]

107. Villéger, R.; Saad, N.; Grenier, K.; Falourd, X.; Foucat, L.; Urdaci, M.C.; Bressollier, P.; Ouk, T.S. Characterization of lipoteichoic acid structures from three probiotic Bacillus strains: Involvement of d-alanine in their biological activity. Antonie Van Leeuwenhoek 2014, 106, 693-706. [CrossRef] [PubMed]

108. Den Camp, H.J.M.O.; Veerkamp, J.H.; Oosterhof, A.; van Halbeek, H. Structure of the lipoteichoic acids from Bifidobacterium bifidum spp. pennsylvanicum. Biochim. Biophys. Acta BBA Lipids Lipid Metab. 1984, 795, 301-313. [CrossRef]

109. Ginsburg, I. Role of lipoteichoic acid in infection and inflammation. Lancet Infect. Dis. 2002, 2, 171-179. [CrossRef]

110. Weill, F.S.; Cela, E.M.; Paz, M.L.; Ferrari, A.; Leoni, J.; González-Maglio, D.H. Lipoteichoic acid from Lactobacillus rhamnosus GG as an oral photoprotective agent against UV-induced carcinogenesis. Br. J. Nutr. 2013, 109, 457-466. [CrossRef] [PubMed]

111. Brauweiler, A.M.; Goleva, E.; Leung, D.Y.M. Staphylococcus aureus Lipoteichoic Acid Damages the Skin Barrier through an IL-1-Mediated Pathway. J. Investig. Dermatol. 2019, 139, 1753-1761. [CrossRef] [PubMed]

112. Coley, J.; Duckworth, M.; Baddiley, J. Extraction and purification of lipoteichoic acids from gram-positive bacteria. Carbohydr. Res. 1975, 40, 41-52. [CrossRef]

113. Morath, S.; Geyer, A.; Hartung, T. Structure-function relationship of cytokine induction by lipoteichoic acid from Staphylococcus aureus. J. Exp. Med. 2001, 193, 393-397. [CrossRef]

114. Mays, Z.J.; Nair, N.U. Synthetic biology in probiotic lactic acid bacteria: At the frontier of living therapeutics. Curr. Opin. Biotechnol. 2018, 53, 224-231. [CrossRef]

115. Felis, G.E.; Salvetti, E.; Torriani, S. Systematics of Lactic Acid Bacteria: Current Status. In Biotechnology of Lactic Acid Bacteria: Novel Applications, 2nd ed.; John Wiley \& Sons, Ltd.: Chichester, UK, 2015; pp. $25-31$.

116. Ogawa, J.; Kishino, S.; Ando, A.; Sugimoto, S.; Mihara, K.; Shimizu, S. Production of conjugated fatty acids by lactic acid bacteria. J. Biosci. Bioeng. 2005, 100, 355-364. [CrossRef]

117. Lee, J.; Lee, M.H.; Cho, E.J.; Lee, S. High-yield methods for purification of $\alpha$-linolenic acid from Perilla frutescens var. japonica oil. Appl. Biol. Chem. 2016, 59, 89-94. [CrossRef]

118. Ayorinde, F.O.; Osman, G.; Shepard, R.L.; Powers, F.T. Synthesis of azelaic acid and suberic acid from Vernonia galamensis oil. J. Am. Oil Chem. Soc. 1988, 65, 1774-1777. [CrossRef]

119. Choi, K.; Jeon, B.S.; Kim, B.C.; Oh, M.K.; Um, Y.; Sang, B.I. In situ biphasic extractive fermentation for hexanoic acid production from sucrose by Megasphaera elsdenii NCIMB 702410. Appl. Biochem. Biotechnol. 2013, 171, 1094-1107. [CrossRef] [PubMed]

120. Kandasamy, V.; Liu, J.; Dantoft, S.H.; Solem, C.; Jensen, P.R. Synthesis of (3R)-acetoin and 2,3-butanediol isomers by metabolically engineered Lactococcus lactis. Sci. Rep. 2016, 6. [CrossRef] [PubMed]

121. Yang, Z.; Suomalainen, T.; Mäyrä-Mäkinen, A.; Huttunen, E. Antimicrobial activity of 2-Pyrrolidone-5-Carboxylic acid produced by lactic acid bacteria. J. Food Prot. 1997, 60, 786-790. [CrossRef]

122. Le Lay, C.; Coton, E.; Le Blay, G.; Chobert, J.M.; Haertlé, T.; Choiset, Y.; Van Long, N.N.; Meslet-Cladière, L.; Mounier, J. Identification and quantification of antifungal compounds produced by lactic acid bacteria and propionibacteria. Int. J. Food Microbiol. 2016, 239, 79-85. [CrossRef]

123. Parada, J.L.; Caron, C.R.; Medeiros, A.B.P.; Soccol, C.R. Bacteriocins from lactic acid bacteria: Purification, properties and use as biopreservatives. Braz. Arch. Biol. Technol. 2007, 50, 521-542. [CrossRef]

124. Ebner, P.; Reichert, S.; Luqman, A.; Krismer, B.; Popella, P.; Götz, F. Lantibiotic production is a burden for the producing staphylococci. Sci. Rep. 2018, 8. [CrossRef] 
125. Corsetti, A.; Gobbetti, M.; Rossi, J.; Damiani, P. Antimould activity of sourdough lactic acid bacteria: Identification of a mixture of organic acids produced by Lactobacillus sanfrancisco CB1. Appl. Microbiol. Biotechnol. 1998, 50, 253-256. [CrossRef]

126. Kwak, M.K.; Liu, R.; Kwon, J.O.; Kim, M.K.; Kim, A.H.; Kang, S.O. Cyclic dipeptides from lactic acid bacteria inhibit proliferation of the influenza a virus. J. Microbiol. 2013, 51, 836-843. [CrossRef]

127. Ryan, L.A.M.; Fabio, D.B.; Arendt, E.K.; Koehler, P. Detection and quantitation of 2,5-diketopiperazines in wheat sourdough and bread. J. Agric. Food Chem. 2009, 57, 9563-9568. [CrossRef]

128. Raveschot, C.; Cudennec, B.; Coutte, F.; Flahaut, C.; Fremont, M.; Drider, D.; Dhulster, P. Production of bioactive peptides by Lactobacillus species: From gene to application. Front. Microbiol. 2018, 9, 2354. [CrossRef]

129. Oberman, H.; Piatkiewicz, A.; Libudzisz, Z. Production of diacetyl and acetoin by lactic acid bacteria. Food Nahrung. 1982, 26, 615-623. [CrossRef]

130. Krampitz, L.O. Preparation and determination of acetoin, diacetyl, and acetolactate. Methods Enzymol. 1957, 3, 277-283. [CrossRef]

131. Liu, Q.; Huang, X.; Yang, D.; Si, T.; Pan, S.; Yang, F. Yield improvement of exopolysaccharides by screening of the Lactobacillus acidophilus ATCC and optimization of the fermentation and extraction conditions. EXCLI J. 2016, 15, 119-133. [CrossRef] [PubMed]

132. Niku-Paavola, M.-L.; Laitila, A.; Mattila-Sandholm, T.; Haikara, A. New types of antimicrobial compounds produced by Lactobacillus plantarum. J. Appl. Microbiol. 1999, 86, 29-35. [CrossRef]

133. Lavermicocca, P.; Valerio, F.; Evidente, A.; Lazzaroni, S.; Corsetti, A.; Gobbetti, M. Purification and characterization of novel antifungal compounds from the sourdough Lactobacillus plantarum strain 21B. Appl. Environ. Microbiol. 2000, 66, 4084-4090. [CrossRef]

134. Vollenweider, S.; Grassi, G.; König, I.; Puhan, Z. Purification and structural characterization of 3-hydroxypropionaldehyde and its derivatives. J. Agric. Food Chem. 2003, 51, 3287-3293. [CrossRef]

135. Patra, F.; Tomar, S.K.; Arora, S. Technological and functional applications of low-calorie sweeteners from lactic acid bacteria. J. Food Sci. 2009, 74, R16-R23. [CrossRef]

136. Leblanc, J.G.; Laiño, J.E.; del Valle, M.J.; Vannini, V.; van Sinderen, D.; Taranto, M.P.; de Valdez, G.F.; de Giori, G.S.; Sesma, F. B-Group vitamin production by lactic acid bacteria - current knowledge and potential applications. J. Appl. Microbiol. 2011, 111, 1297-1309. [CrossRef]

137. Ge, Y.-Y.; Zhang, J.-R.; Corke, H.; Gan, R.-Y. Screening and Spontaneous Mutation of Pickle-Derived Lactobacillus plantarum with Overproduction of Riboflavin, Related Mechanism, and Food Application. Foods 2020, 9, 88. [CrossRef]

138. Bertsch, A.; Roy, D.; LaPointe, G. Enhanced exopolysaccharide production by Lactobacillus rhamnosus in co-culture with Saccharomyces cerevisiae. Appl. Sci. 2019, 9. [CrossRef]

139. Ziadi, M.; Bouzaiene, T.; M'Hir, S.; Zaafouri, K.; Mokhtar, F.; Hamdi, M.; Boisset-Helbert, C. Evaluation of the efficiency of ethanol precipitation and ultrafiltration on the purification and characteristics of exopolysaccharides produced by three lactic acid bacteria. Biomed. Res. Int. 2018, 2018. [CrossRef] [PubMed]

140. Tagliazucchi, D.; Martini, S.; Solieri, L. Bioprospecting for Bioactive Peptide Production by Lactic Acid Bacteria Isolated from Fermented Dairy Food. Fermentation 2019, 5, 96. [CrossRef]

141. Claus, H.; Mojsov, K. Enzymes for wine fermentation: Current and perspective applications. Fermentation 2018, 4, 52. [CrossRef]

142. Arancon, R.A.D.; Lin, C.S.K.; Chan, K.M.; Kwan, T.H.; Luque, R. Advances on waste valorization: New horizons for a more sustainable society. Energy Sci. Eng. 2013, 1, 53-71. [CrossRef]

143. Bustamante, D.; Tortajada, M.; Ramón, D.; Rojas, A. Production of D-Lactic Acid by the Fermentation of Orange Peel Waste Hydrolysate by Lactic Acid Bacteria. Fermentation 2019, 6, 1. [CrossRef]

144. Olszewska-Widdrat, A.; Alexandri, M.; López-Gómez, J.P.; Schneider, R.; Mandl, M.; Venus, J. Production and purification of L-lactic acid in lab and pilot scales using sweet sorghum juice. Fermentation 2019, 5. [CrossRef]

145. Ghimire, A.; Trably, E.; Frunzo, L.; Pirozzi, F.; Lens, P.N.L.; Esposito, G.; Cazier, E.A.; Escudié, R. Effect of total solids content on biohydrogen production and lactic acid accumulation during dark fermentation of organic waste biomass. Bioresour. Technol. 2018, 248, 180-186. [CrossRef]

146. Nguyen, Q.A.; Cho, E.; Trinh, L.T.P.; Jeong, J.S.; Bae, H.J. Development of an integrated process to produce D-mannose and bioethanol from coffee residue waste. Bioresour. Technol. 2017, 244, 1039-1048. [CrossRef] 
147. López-Gómez, J.P.; Alexandri, M.; Schneider, R.; Latorre-Sánchez, M.; Lozano, C.C.; Venus, J. Organic fraction of municipal solid waste for the production of L-lactic acid with high optical purity. J. Clean. Prod. 2019, 247, 119165. [CrossRef]

148. Berbegal, C.; Fragasso, M.; Russo, P.; Bimbo, F.; Grieco, F.; Spano, G.; Capozzi, V. Climate changes and food quality: The potential of microbial activities as mitigating strategies in the wine sector. Fermentation 2019, 5, 85. [CrossRef]

149. Sijtsema, S.J.; Snoek, H.M.; van Haaster-de Winter, M.A.; Dagevos, H. Let's Talk about Circular Economy: A Qualitative Exploration of Consumer Perceptions. Sustainability 2019, 12, 286. [CrossRef]

150. De Vero, L.; Boniotti, M.B.; Budroni, M.; Buzzini, P.; Cassanelli, S.; Comunian, R.; Gullo, M.; Logrieco, A.F.; Mannazzu, I.; Musumeci, R.; et al. Preservation, characterization and exploitation of microbial biodiversity: The perspective of the italian network of culture collections. Microorganisms 2019, 7, 685. [CrossRef] [PubMed]

(C) 2020 by the authors. Licensee MDPI, Basel, Switzerland. This article is an open access article distributed under the terms and conditions of the Creative Commons Attribution (CC BY) license (http://creativecommons.org/licenses/by/4.0/). 